\title{
Efektivitas Permainan Detumbar (Dengarkan, Temukan gambar) terhadap Minat Belajar Anak Usia Dini
}

\author{
Tri Yuli Ayuningtyas ${ }^{1}$, Lanny Wijayaningsih ${ }^{2 \bowtie}$ \\ Pendidikan Guru Pendidikan Anak Usia Dini, Universitas Kristen Satya Wacana \\ DOI: $10.31004 /$ obsesi.v5i1.724
}

\begin{abstract}
Abstrak
Tujuan penelitian ini adalah untuk mengetahui efektivitas permainan Detumbar terhadap minat belajar anak usia dini di TK Realfun Rainbow Salatiga. Metode yang digunakan dalam penelitian ini yaitu pra-eksperimen menggunakan satu kelompok pretest-posttest dengan subjek penelitian berjumlah 13 anak. Teknik pengumpulan data yang digunakan menggunakan observasi dengan instrumen penilitian berupa catatan anekdot. Teknik analisis data yang digunakan adalah Uji-t Paired Sample Test. Penerapan pembelajaran di beberapa kelas sentra terkesan membosankan bagi anak. Hasil penelitian menunjukkan bahwa permainan Detumbar efektif terhadap minat belajar anak TK Tingkat A di Realfun Rainbow, yaitu sebanyak 61,5\% dari 13 anak di kelas TK Tingkat A mengalami peningkatan terhadap minat belajar. Kebaruan dalam penelitian ini adalah cara bermain permainan Detumbar. Permainan Detumbar berdampak positif terhadap minat belajar anak TK Tingkat A di Realfun Rainbow.
\end{abstract}

Kata Kunci: minat belajar; media audio visual; permainan detumbar.

\begin{abstract}
The strudy aims to determine the effectiveness of the Detumbar game on early childhood learning interest in Kindergarten Realfun Rainbow Salatiga. The method used in this research is pre-experiment using a pretest-posttest group with 13 children as research subjects. Data collection techniques used observation instruments such as notes anecdotal research. The data analysis technique used the Paired Sample Test $\mathrm{t}$-test. The practices of learning in several center classes seems boring to children. The results showed that Detumbar game has an effectivity for learning interest of Kindergarten Level A children at Rainbow Realfun, as much as $61.5 \%$ of the 13 children in the Level A Kindergarten class experienced an increase in interest in learning. The novelty in this research is how to play the game Detumbar. Detumbar game has a positive impact on the learning interest of Kindergarten Level A children at Realfun Rainbow.
\end{abstract}

Keywords: interest to learn; audio visual media; detumbar game.

Copyright (c) 2020 Tri Yuli Ayuningtyas, Lanny Wijayaningsih

$\triangle$ Corresponding author:

Email Address : lanny.wijayaningsih@yahoo.com ( Salatiga, Jawa Tengah, Indonesia)

Received 21 August 2020, Accepted 24 August 2020, Published 25 August 2020 


\section{PENDAHULUAN}

Minat belajar bagi anak sangat dibutuhkan agar anak dapat belajar dengan baik. Schunk (2010) dalam Astriya dan Kuntoro (2015) menyatakan bahwa pentingnya minat adalah orang akan belajar atau bekerja dengan baik apabila mereka berminat dan tidak akan belajar atau bekerja dengan baik apabila mereka tidak berminat. Ubaidillah (2020) mendefinisikan, minat adalah kecenderungan yang dapat menetap dalam diri seseorang untuk memperhatikan dan mengenang beberapa kegiatan atau bidang tertentu serta merasa senang berkecimpung dalam bidang tersebut. Jika anak tidak berminat dalam suatu pembelajaran atau bidang tertentu maka anak tidak akan memperhatikan, tidak tertarik dan tidak terlibat dalam melakukan pembelajaran. Menurut Nasution dkk., (2020) minat belajar anak tidak dapat berkembang dengan baik jika tidak didukung dengan stimulus yang dapat memicu minat. Minat belajar anak akan lebih tinggi jika menggunakan media yang dirasa lebih menarik dan menyenangkan bagi anak.

Zaini dan Dewi, (2017) menjelaskan bahwa secara umum media pembelajaran adalah media atau alat yang menjadi perantara dalam menyampaikan pembelajaran serta memperlancar interaksi antara guru dengan anak. Sama halnya dengan yang di jelaskan oleh Ariyanto dkk., (2018) bahwa media pembelajaran adalah suatu alat untuk meningkatkan proses belajar mengajar untuk mencapai tujuan pembelajaran supaya lebih baik. Zaini dan Dewi, (2017) berpendapat bahwa media banyak memberikan dampak positif bagi anak, baik yang berkenaan dengan proses perkembangan otak maupun yang berhubungan dengan kreativitas.

Menurut Fithri dan Pradipta (2017) media audio visual adalah media intruksional modern yang sesuai dengan perkembangan zaman yaitu kemajuan ilmu pengetahuan dan teknologi sehingga guru tidak hanya berperan sebagai penyampai materi namun juga berperan menjadi fasilitator dengan memberikan kemudahan bagi anak untuk belajar. Media audio visual merupakan media yang terdiri dari gambar dan suara yang digunakan sebagai media perantara untuk menjelaskan suatu pembelajaran (Zeptyani dan Wiarta, 2020). Media audio visual adalah cara untuk menghasilkan atau menyampaikan materi dengan menggunakan mesin-mesin mekanis dan elektronik untuk menyajikan pesan-pesan dalam pengajaran yang dilakukan oleh guru (Margaretha dan Pura, 2019).

Salah satu kegiatan pembelajaran yang dapat diterapkan pada anak usia dini adalah bermain. Bermain merupakan cara belajar terbaik pada anak prasekolah (Fauziddin, 2016). Bermain merupakan salah satu metode belajar bagi anak usia dini. Pembelajaran bagi anak usia dini tentunya diterapkan dengan cara yang menarik dan mudah diikuti oleh anak sehingga pembelajaran tersebut lebih efektif dan bermakna bagi anak. Untuk itu penerapan pembelajaran disesuaikan dengan pembelajaran anak usia dini yaitu melalui metode permainan.

Permainan adalah salah satu bentuk aktivitas sosial yang dominan pada awal masa anak-anak (Hasanah, 2016). Anak mengeksplorasi permainan yang dimainkan baik secara individu maupun dalam kelompok, secara tidak sadar anak mempelajari sesuatu melalui bermain, seperti belajar mengendalikan diri sendiri, memahami kehidupan, memahami dunianya. Melalui bermain anak mengembangkan motorik, kognitif, bahasa, sosial, emosi, dan kretivitas. Jika seorang anak memainkan mainan mobil-mobilan dan menjalankannya seolah-olah berada di lintasan balap, padahal tidak ada lintasan yang terlihat, maka dapat dikatakan anak tersebut sedang bermain dan berimajinasi dengan permainan yang ia ciptakan sendiri.

Ilustrasi di atas menggambarkan bahwa anak berimajinasi menggunakan suatu media, anak menciptakan cara bermainnya sendiri. Selain anak dapat melakukan kegiatan melalui permainan yang ia ciptakan sendiri, anak juga bisa melakukan permainan yang dibuat oleh guru di kelas. Seperti hasil penelitian dari Sunanti dkk., (2016) mengenai Penerapan Permainan Tradisional Galah bandung Profil Kecerdasan Bodily-Kinesthetic, menunjukan bahwa profil akhir kelompok eksperimen di Taman Kanak-kanak Siti Fatimah 
sesudah penerapan permainan galah bandung menunjukkan sebanyak $79 \%$ anak yang muncul kecerdasan bodily-kinesthetic dan sebanyak $21 \%$ anak yang belum muncul dalam kecerdasan bodily-kinesthetic. Melalui suatu permainan dapat membuat pembelajaran yang berlangsung di kelas menjadi menyenangkan.

Seperti yang terlihat permasalahan pada minat belajar anak, di sekolah TK Tingkat A Realfun Rainbow pada beberapa kelas sentra belum banyak menggunakan permainan, peneliti melihat bahwa anak-anak kurang tertarik dan merasa bosan dalam melakukan pembelajaran yang dibawakan oleh guru. Dibuktikan dengan anak yang tidak mau menirukan instruksi, bermain sendiri, bermain dengan teman dan berbicara sendiri. Melalui mendengar akan menambah kosakata yang dimiliki anak, anak berimajinasi, dan melatih pendengaran anak. Untuk itu perlu diterapkan dalam suatu permainan, supaya kegiatan mendengarkan lebih menyenangkan, menantang, sehingga menumbuhkan minat belajar anak. Gordon (2009) Gunawan dkk., (2018) mendengar aktif merupakan salah satu cara yang efektif untuk membangun komunikasi dan interaksi dengan anak.

Untuk menumbuhkan minat belajar anak usia dini, pendidik perlu membuat kegiatan pembelajaran yang menarik salah satunya melalui permainan agar anak merasa tertari dan senang untuk mengikuti proses pembelajaran di kelas. Guru dapat memanfaatkan teknologi sebagai media pembelajarannya karena guru memiliki peran penting dalam pengelolaan pembelajaran di kelas, yaitu pemanfaatan speaker sebagai alat bantu dengar, gambar sebagai alat bantu pandang, dan video sebagai alat bantu dengar dan pandang. Azhari (2015) dalam Putri dkk., (2020) yang menyebutkan bahwa penggunaan media pembelajaran dapat memperjelas penyajian pesan dan informasi sehingga dapat memperlancar dan meningkatkan proses dan hasil aktivitas pembelajaran.

Seperti halnya penerapan pembelajaran pada tema tertentu yang dapat memanfaatkan teknologi sebagai media pembelajaran seperti pada tema profesi, rekreasi, dan kendaraan yang memerlukan media tambahan dalam menerapkan materi pembelajaran supaya lebih menyenangkan sehingga menumbuhkan minat anak untuk belajar. Pada kenyataannya pembelajaran tersebut diterapkan dengan metode ceramah, tanya-jawab, pemberian tugas dan belum banyaknya permainan yang diterapkan sebagai media pembelajaran yang terkesan membosankan bagi anak usia dini sehingga kurangnya minat anak untuk belajar. Oleh karena itu anak banyak yang tidak mau menirukan yang diajarkan oleh guru, diam, bermain dengan teman, bermain sendiri dan berbicara sendiri, hal itu membuat anak anak tidak berperan aktif dalam pembelajaran yang sedang berlangsung.

Berdasarkan permasalahan di atas peneliti tertarik menggunakan permainan Detumbar (Dengarkan, Temukan Gambar) ini berawal dari pengamatan di TK Tingkat A Realfun Rainbow yang membutuhkan media pembelajaran tambahan karena anak-anak mengalami kesulitan dalam memahami tema pembelajaran profesi, rekreasi, kendaraan, yang disampaikan oleh guru. Oleh karena itu dalam penelitian ini peneliti menggunakan permainan Detumbar untuk menumbuhkan minat belajar anak TK Tingkat A di TK Realfun Rainbow. Melalui permainan Detumbar anak dapat belajar lebih menyenangkan karena pembelajaran yang dilakukan melalui permainan. Anak akan terlibat aktif dalam pembelajaran karena melakukan permainan bersama teman-temannya untuk mendengarkan suara, mencari gambar, dan melihat gambar dan video di dalam permainan Detumbar sehingga membuat anak aktif bergerak, berbicara, dan berkomunikasi dengan temannya.

Permainan Detumbar merupakan permainan yang dirancang untuk menumbuhkan minat belajar anak yang mana di dalam permainan Detumbar ini dapat melatih pendengaran, melatih perhatian, imajinasi, dan penglihatan anak. Permainan Detumbar diawali dengan cerita dari permainan lalu anak diminta untuk mendengarkan suara yang diputar di laptop dengan pengeras suara speaker, laptop tersebut ditutup dengan kotak supaya anak fokus dengan suara yang diputar, suara yang diputar menggambarkan suasana/situasi tertentu sesuai tema pembelajaran. Melalui media ini dapat memicu ketertarikan dan perhatian anak karena merasa penasaran dengan sumber suara yang 
DOI: 10.31004/obsesi.v5i1.724

ditimbulkan, dengan begitu anak akan mulai terlibat dalam pembelajaran yang dilaksanakan.

Kemudian anak diminta untuk mencari gambar sebagai simbol dari suasana/situasi suara yang sudah diputar di laptop. Diakhir pembelajaran akan dimunculkan video tentang suasana/situasi dari suara yang di dengarkan kepada anak. Ketertarikan anak muncul juga saat mencari gambar dengan begitu anak melakukan atau mengerjakan sesuatu yang membuat anak merasa senang.

Penelitian ini diharapkan dapat menumbuhkan minat belajar anak usia 4-5 tahun dan menjadi reverensi bagi guru kelas dalam menyajikan pembelajaran di kelas dengan lebih memperhatikan minat anak dalam belajar.

\section{METODOLOGI}

Jenis penelitian yang digunakan adalah jenis penelitian kuantitatif yaitu penelitian pra-eksperimen dengan menggunakan satu kelompok pretest-posttest sebagai kelompok eksperimen. Pemilihan subjek penelitian dalam pra-eksperimen dilakukan dengan cara purposive, yakni dipilih dengan ciri-ciri tertentu sesuai ketentuan si peneliti (Soesilo, 2015:35). Subjek penelitian yang digunakan adalah anak-anak TK Tingkat A di Realfun Rainbow. Anak yang akan menjadi subjek penelitian berjumlah 13 anak di TK tingkat A.

Variabel bebas (variabel $\mathrm{X}$ ) dalam penelitian ini adalah penggunaan permainan dengarkan dan temukan gambar sebagai media pembelajaran, sedangkan variabel terikat (variabel Y) dalam penelitian ini adalah minat belajar anak usia dini. Teknik pengumpulan data yang digunakan dalam penelitian ini adalah observasi. Teknik analisis data menggunakan Uji-t yaitu dengan Paired Sample Test. Data tersebut menguji satu sampel yaitu minat belajar anak usia dini pada TK Tingkat A di Realfun Rainbow.

Penelitian ini dilakukan pada bulan Agustus dan Oktober 2019. Pelaksanaan observasi awal di TK Tingkat A dilakukan pada tanggal 27 - 29 Agustus dan 8 Oktober 2019. Pelaksanaan pemberian perlakuan dilakukan pada tanggal 11 - 17 Oktober 2019. Berikut ini adalah alur pelaksanaan penelitian :

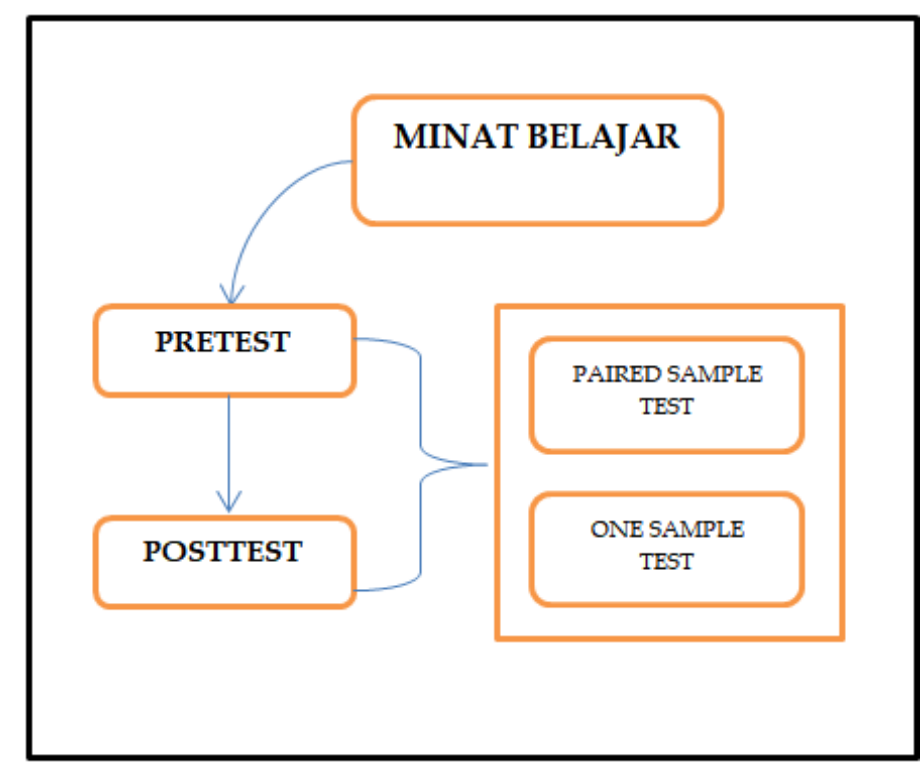

Bagan 1. Alur Penelitian

Instrumen penelitian yang digunakan dalam penelitian ini berupa catatan anekdot. Sebelum membuat instrumen penelitian perlu ditetapkan indikator-indikator pada variabel yang akan diteliti (Sugiyono, 2012). Indikator-indikator yang digunakan dalam penelitian ini sebagai berikut : 
Tabel 1. Indikator Minat Belajar Anak

\begin{tabular}{|c|c|c|c|}
\hline No & Indikator & $\mathrm{Ya}$ & Tidak \\
\hline 1 & $\begin{array}{l}\text { Perasaan senang: } \\
\text { a. Anak melakukan kegiatan dengan semangat. } \\
\text { b. Anak melakukan kegiatan tanpa merasa terpaksa. }\end{array}$ & & \\
\hline 2 & $\begin{array}{l}\text { Ketertarikan siswa: } \\
\text { a. Anak dapat berinteraksi dengan guru dan teman dalam } \\
\text { kegiatan pembelajaran. } \\
\text { b. Anak menunjukan keinginan untuk melihat/memegang media } \\
\text { pembelajaran. } \\
\text { c. Anak menunjukan keinginan untuk melakukan kegiatan } \\
\text { pembelajaran. } \\
\text { d. Anak menunjukan pengalaman afektif. }\end{array}$ & & \\
\hline 3 & $\begin{array}{l}\text { Perhatian siswa : } \\
\text { a. Anak dapat berkonsentrasi terhadap kegiatan pembelajaran. }\end{array}$ & & \\
\hline 4 & $\begin{array}{l}\text { Keterlibatan siswa: } \\
\quad \text { a. Anak dapat melakuka kegiatan pembelajaran. }\end{array}$ & & \\
\hline
\end{tabular}

Tabel 2. Indikator Permainan Detumbar

\begin{tabular}{|c|c|c|c|}
\hline No & \multicolumn{1}{|c|}{ Indikator } & Ya & Tidak \\
\hline 1 & $\begin{array}{l}\text { Mendengarkan : } \\
\text { a. Anak dapat berkonsentrasi mendengarkan suara ketika suara } \\
\text { mulai diputar dari laptop menggunakan pengeras suara tanpa } \\
\text { adanya gambar. }\end{array}$ & & \\
\hline 2 & $\begin{array}{l}\text { Menyimak: } \\
\text { a. Anak dapat memahami bahasa lisan bersumber dari pengeras } \\
\text { suara dan video. }\end{array}$ & $\begin{array}{l}\text { Melihat : } \\
\text { a. Anak dapat mencari gambar yang sesuai dengan suara diputar } \\
\text { diawal kegiatan. } \\
\text { b. Anak dapat menyimak video untuk memastikan gambar yang } \\
\text { diambil oleh anak sama dengan suara yang diputar diawal } \\
\text { permainan. }\end{array}$ & \\
\hline
\end{tabular}

\section{HASIL DAN PEMBAHASAN}

Berdasarkan data yang harus dicapai oleh anak yaitu skor maksimum 16 dan minimum 8. Kategori interpretasi data dibagi menjadi 2 (kategori Ya dan Tidak) sedangkan panjang interval minat belajar $8 / 2=4$. Data Pretest merupakan data awal yang diambil oleh peneliti untuk mengetahui minat belajar anak terhadap pembelajaran sebelum diberi perlakuan. Berdasarkan tabel pretest dapat diketahui hasil persentase dari hasil pengamatan yang dapat disimpulkan bahwa anak TK Tingkat A di Realfun Rainbow Salatiga kategori nilai rata-rata jawaban Ya berdasarkan indikator ada 38,5\% dari 5 anak dan ada rata-rata jawaban Tidak dari indikator 61,5\% dari 8 anak dari jumlah 13 anak yang diobservasi. Berdasarkan data awal dapat dilihat mean atau rata-rata 13.8654. Dari data tersebut dapat disimpulkan bahwa minat belajar anak TK Tingkat A di Realfun Rainbow dalam kategori Tidak (Kurang).

Tabel 3. Kategori Minat Belajar

\begin{tabular}{|l|c|c|c|c|}
\hline \multirow{2}{*}{ Kategori } & \multicolumn{2}{|c|}{ Frekuensi } & \multicolumn{2}{c|}{ Persentase } \\
\cline { 2 - 5 } & Pretest & Posttest & Pretest & Posttest \\
\hline Ya (12-16) & 5 & 8 & $5 / 13 \times 100 \%=38,5 \%$ & $8 / 13 \times 100 \%=61,5 \%$ \\
\hline Tidak (8-11) & 8 & 5 & $8 / 13 \times 100 \%=61,5 \%$ & $5 / 13 \times 100 \%=38,5 \%$ \\
\hline$\sum$ & 13 & 13 & $100 \%$ & $100 \%$ \\
\hline
\end{tabular}

818 | Jurnal Obsesi : Jurnal Pendidikan Anak Usia Dini, 5(1), 2021 


\section{Tabel 4. Descriptive Statistics}

\begin{tabular}{|c|c|c|c|c|c|}
\hline \multicolumn{6}{|c|}{ Descriptive Statistics } \\
\hline & $\mathrm{N}$ & Minimum & Maximum & Mean & Std. Deviation \\
\hline Pretest & 13 & 9.25 & 15.75 & 13.8654 & 1.97013 \\
\hline Posttest & 13 & 13.00 & 16.00 & 15.1346 & 1.04391 \\
\hline Valid N (listwise) & 13 & & & & \\
\hline
\end{tabular}

Berdasarkan tabel posttest dapat diketahui hasil persentase dari hasil pengamatan disimpulkan bahwa anak Taman Kanak-kanak di KB-TK Realfun Rainbow Salatiga kategori nilai rata-rata jawaban Tidak berdasarkan indikator ada 38,5\% dari 5 anak dan ada rata-rata jawaban Ya dari indikator 61,5\% dari 8 anak dari jumlah 13 anak yang diobservasi. Dari Tabel. terdapat mean atau rata-rata hasil posttest adalah 15.1346. Hal tersebut membuktikan bahwa minat belajar anak dengan kategori Ya (Meningkat). Dari data tersebut dapat disimpulkan bahwa Minat Belajar anak TK Tingkat A di Realfun Rainbow Salatiga mengalami adanya peningkatan setelah diberikan perlakuan dalam bentuk pembelajaran yang menggunakan permainan Detumbar.

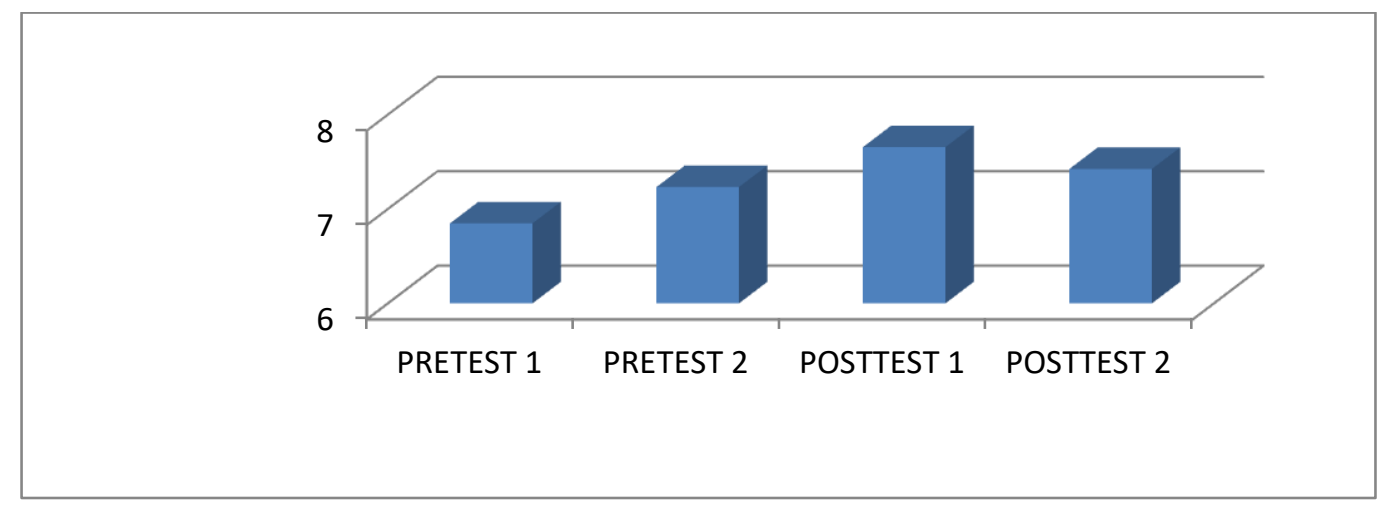

Gambar 1. Grafik Pretest dan Posttest

Grafik diatas menunjukkan tentang hasil rata-rata pretest hingga posttest. Hasil ratarata pretest 1 menunjukkan minat belajar anak di TK Kelas A Realfun Rainbow sebesar 6,8. Hasil rata-rata pretest 2 mulai menunjukkan adanya peningkatan terhadap minat belajar yaitu sebesar 7,2. Pada hasil rata-rata posttest 1 juga menunjukkan adanya peningkatan yang cukup besar yaitu 7,6. Namun pada hasil posttest 2 hasil rata-rata mengalami penurunan menjadi 7,4.

Tabel 5. Paired Samples Statistics

\begin{tabular}{|c|c|c|c|c|c|}
\hline \multicolumn{6}{|c|}{ Paired Samples Statistics } \\
\hline & & Mean & $\mathrm{N}$ & Std. Deviation & $\begin{array}{c}\text { Std. Error } \\
\text { Mean }\end{array}$ \\
\hline \multirow[t]{2}{*}{ Pair 1} & Pretest & 13.8654 & 13 & 1.97013 & .54642 \\
\hline & Posttest & 15.1346 & 13 & 1.04391 & 28953 \\
\hline
\end{tabular}

Tabel 5. Paired Samples Correlations

\begin{tabular}{|c|c|c|c|c|}
\hline \multicolumn{5}{|c|}{ Paired Samples Correlations } \\
\hline & & $\mathrm{N}$ & Correlation & Sig. \\
\hline$\overline{\text { Pair } 1}$ & Pretest \& Posttest & 13 & .478 & .098 \\
\hline
\end{tabular}


Tabel 6. Paired Samples Test

\begin{tabular}{|c|c|c|c|c|c|c|c|c|c|}
\hline \multicolumn{10}{|c|}{ Paired Samples Test } \\
\hline \multicolumn{7}{|c|}{ Paired Differences } & \multirow[b]{3}{*}{$\mathrm{T}$} & \multirow[b]{3}{*}{$\mathrm{df}$} & \multirow{3}{*}{$\begin{array}{l}\text { Sig. (2- } \\
\text { tailed) }\end{array}$} \\
\hline & & \multirow[b]{2}{*}{ Mean } & \multirow{2}{*}{$\begin{array}{c}\text { Std. } \\
\text { Deviation }\end{array}$} & \multirow{2}{*}{$\begin{array}{l}\text { Std. } \\
\text { Error } \\
\text { Mean }\end{array}$} & \multicolumn{2}{|c|}{$\begin{array}{l}\text { 95\% Confidence } \\
\text { Interval of the } \\
\text { Difference }\end{array}$} & & & \\
\hline & & & & & Lower & Upper & & & \\
\hline Pair 1 & $\begin{array}{l}\text { Pretest - } \\
\text { Posttest }\end{array}$ & -1.26923 & 1.73344 & .48077 & -2.31674 & -.22172 & -2.640 & 12 & .022 \\
\hline
\end{tabular}

Hasil dari Uji-t adalah -2.640 dengan mean pretest 13.8654 dan posttest 15.1346 dari 8 item pernyataan minat belajar anak dengan standar deviation pretest 1.97013 dan standar deviation posttest 1.04391. Signifikansi yang didapat adalah 0,098 dengan korelasi 0,478 dan perbedaan pair sample dengan mean -1.26923 dengan signifikansi 0,022. Hasil tersebut didapatkan berdasarkan kondisi kelas sentra yang memiliki fasilitas berbeda didalamnya serta sistem pengajaran yang berbeda disetiap kelas.

Pada saat dilakukan posttest pertama di kelas sentra bermain peran, anak-anak tidak banyak terganggu dengan media yang sudah disiapkan oleh peneliti. Media yang digunakan pada saat posttest pertama berupa projector, speaker, gambar, dan laptop. Karena tata ruang kelas ini cukup luas, saya dapat mengatur sesuai dengan kebutuhan penelitian. Sehingga saya dapat meletakkan speaker yang disembunyikan di dekat tempat duduk siswa, projector dan laptop berada jauh dari tempat duduk siswa. Pada saat posttest kedua dilakukan di sentra yang berbeda yaitu di sentra teknologi dimana tata ruang kelas tersebut memiliki fasilitas LCD TV, speaker home teather, dengan ruang kelas yang tidak terlalu luas. Saat dilakukan perlakuan pada posttest kedua ini anak-anak tidak fokus dalam pembelajaran karena anak-anak terus berdiri dari tempat duduk mereka untuk mencari tahu suara dari video yang di putar.

Menurut Djamarah (2011:166) minat adalah kecenderungan yang menetap untuk memperhatikan dan mengenang beberapa aktivitas. Minat berpengaruh tehadap keinginan anak untuk melakukan suatu aktivitas. Minat dapat dikembangkan apabila dilakukan menggunakan metode yang tepat dan menyenangkan. Seperti yang diungkapkan Bunda Lucy dalam Wirsa dan Saridewi, (2020) bahwa minat anak dapat dikembangkan apabila dilakukan dengan metode-metode yang tepat, misalnya dengan perlakuan metode demonstrasi dengan tujuan untuk mempengaruhi perhatian anak lebih terarah pada materi yang sedang dipelajari serta pengalaman dan kesan sebagai hasil penambahan lebih melekat pada diri anak. Oleh sebab itu guru dituntut untuk kreatif dalam membangkitkan minat anak dalam pembelajaran yang dilakukan di kelas. Minat belajar pada anak usia dini juga dapat tumbuh ketika pembelajaran yang dilakukan disajikan dengan permainan dan media yang beragam sehingga anak memperhatikan terus menerus disertai perasaan senang anak terhadap kegiatan tersebut.

Sekolah ini memiliki sistem kelas sentra dimana setiap kelas menerapkan pembelajaran dengan cara yang berbeda dan aturan dalam kelas yang berbeda. Anak-anak akan berada di sentra yang berbeda setiap harinya. Saat peneliti mencoba mengikuti kegiatan anak-anak TK Tingkat A dalam beberapa kelas sentra, anak-anak terlihat kurang berminat penerapan pembelajaran yang ada. Belum banyaknya permainan yang diterapkan sebagai pembelajaran di kelas dan media pembelajaran dibeberapa sentra yang terkesan membosankan bagi anak sehingga kurangnya minat anak untuk belajar di beberapa kelas sentra. Oleh karena itu anak banyak yang tidak mau menirukan yang diajarkan oleh guru, diam, bermain dengan teman, bermain sendiri dan berbicara sendiri.

Menurut Puspa Putri, (2019) media pembelajaran yang interaktif dapat membantu pengguna untuk belajar secara mandiri serta membantu pengguna untuk mempunyai motivasi yang lebih untuk belajar. Kembuan dan Irwansyah, (2019) berpendapat bahwa 
media pembelajaran telah muncul dalam berbagai variasi untuk membantu para pelajar/siswa dalam proses pembelajaran, adanya peralatan audio-visual yang sedang berkembang saat ini yang dapat digunakan dalam melengkapi guru dalam pembelajaran yang efektif kepada siswa.

Dalam penelitian ini peneliti menggunakan media yang sudah ada di sekolah, berupa laptop, proyektor, dan speaker. Namun penggunaan media yang ada kurang efektif sehingga peneliti menambahkan flash card sebagai media pelengkap. Hal baru dari penelitian ini adalah cara bermainnya. Permainan Detumbar dimainkan dengan cara, pertama guru menjelaskan gambar yang ada di flash card, setelah itu anak diminta mendengarkan suara yang bersumber dari speaker tanpa melihat gambar. Kemudian anak akan diminta untuk mencari gambar pada flash card yang berhubungan dengan suara yang telah anak dengar sebelumnya. Setelah anak berhasil mengumpulkan flash card, peneliti memutarkan sebuah tayangan video yang di awal permainan sudah anak dengarkan suaranya.

Permainan Detumbar memberikan dampak yang positif terhadap minat belajar anak. Hal ini terlihat saat penelitian berlangsung anak lebih antusias dalam pembelajaran yang dilakukan, anak lebih memperhatikan pembelajaran, anak tertarik untuk mengikuti pembelajaran, dan juga anak terlibat aktif dalam pembelajaran yang dilakukan.

Berdasarkan penelitian sebelumnya yang dilakukan oleh Purba dan Larosa (2016) menunjukan bahwa minat belajar anak dapat ditingkatkan dengan menggunakan teknik kolase dari bahan plastik bekas jajanan. Hal ini dapat dilihat dari peningkatan yang signifikan pada siklus II dalam penelitian tersebut. Apabila bahan ajar yang digunakan tidak memiliki daya tarik bagi anak maka minat belajar yang di miliki akan berkurang dan anak tidak dapat menerima pembelajaran dengan baik. Karena minat memiliki pengaruh yang cukup besar dalam kegiatan belajar pada anak usia dini (Munawir, 2018).

\section{SIMPULAN}

Penggunaan permainan Detumbar untuk menumbuhkan minat belajar cukup efektif pada anak TK Tingkat A di Realfun Rainbow Salatiga. Hal ini terlihat saat anak-anak mengikuti pembelajaran lebih bersemangat dan antusias serta anak memiliki ketertarikan pada media yang digunakan. Harapan peneliti kedepannya semoga guru-guru lebih kreatif membuat media pembelajaran yang dapat menarik minat belajar anak.

\section{UCAPAN TERIMA KASIH}

Terima kasih kepada Kepala Sekolah KB-TK Realfun Rainbow yang telah berkenan memberikan izin kepada peneliti sehingga dapat terlaksa dengan baik. Terima kasih kepada guru kelas serta pihak-pihak yang terlibat dalam proses pengambilan data dari awal hingga akhir penelitian ini.

\section{DAFTAR PUSTAKA}

Ariyanto, A., Priyayi, D. F., \& Dewi, L. (2018). Penggunaan Media Pembelajaran Biologi Di Sekolah Menrngah Atas (SMA) Swasta Salatiga. Bioedukasi (Jurnal Pendidikan Biologi), 9(1), 1. https://doi.org/10.24127/ bioedukasi.v9i1.1377

Astriya, B. R. I., \& Kuntoro, S. A. (2015). Pengembangan Kreativitas dan Minat Belajar Anak Usia 3-4 Tahun Melalui Permainan Konstruktif. Jurnal Pendidikan Dan Pemberdayaan Masyarakat, 2(2), 131. https://doi.org/10.21831/jppm.v2i2.6329

Djamarah, S. B. (2011). Psikologi Belajar. Rineka Cipta.

Fauziddin, M. (2016). Pembelajaran Agama Islam Melaui Bermain Pada Anak Usia Dini. Pendidikan Anak Usia Dini, https://doi.org/https://doi.org/https://doi.org/10.31004/obsesi.v2i2.37

Fithri, R., \& Pradipta, R. (2017). Penerapan Media Audio Visual Untuk Meningkatkan Perekembangan Moral Anak Usia 5-6 Tahun di PAUD Cemara Indah Kota Pekan 
Baru. PAUD Lectura : Jurnal Pendidikan Anak Usia Dini, 1(1), 58-71. https:// doi.org/https:// doi.org/10.31849/paudlectura.v1i1.504

Gunawan, O., Lestari Suharso, P., \& Pepen Daengsari, D. (2018). Program Mendengar Aktif untuk Ayah dengan Anak Usia 4 Hingga 6 Tahun. Jurnal Intervensi Psikologi (JIP), 10(2), 115-132. https:// doi.org/10.20885/intervensipsikologi.vol10.iss2.art4

Hasanah, U. (2016). Pengembangan Kemampuan Fisik Motorik Melalui Permainan Tradisional Bagi Anak Usia Dini. Jurnal Pendidikan Anak, 5(1). https:// doi.org/10.21831/jpa.v5i1.12368

Kembuan, E. M., \& Irwansyah, I. (2019). Peran Teknologi Audio-Visual dalam Pengembangan Pembelajaran Anak di Sekolah Dasar Karya Anak Bangsa di Manado [The Role of Technology and Audio-Visual Media in Learning Development at Anak Bangsa Elementary School, Manado]. Polyglot: Jurnal Ilmiah, 15(1), 73. https:// doi.org/10.19166/pji.v15i1.1311

Margaretha, L., \& Pura, D. N. (2019). Pengembangan Model Media Audio-Visual untuk Meningkatkannilai-Nilai Agama dan Moral Anak Usia Dini Kota Bengkulu. KINDERGARTEN: Journal of Islamic Early Childhood Education, 2(2), 167. https:/ / doi.org/10.24014/kjiece.v2i2.9060

Munawir, A. S. (2018). Meningkatkan Minat Belajar Anak Melalui Pembelajaran Di Luar Kelas Pada Anak Kelompok A TK Joyful Kids Palu. ECIJ, 1(2), 38-44. https:/ / doi.org/10.31934/eceij.v1i2.514

Nasution, R. H., Hapidin, H., \& Fridani, L. (2020). Pengaruh Pembelajaran ICT dan Minat Belajar terhadap Kesiapan Membaca Anak Usia Dini. Jurnal Obsesi : Jurnal Pendidikan Anak Usia Dini. https:/ / doi.org/10.31004/obsesi.v4i2.411

Purba, N., \& Larosa, M. (2016). Meningkatkan Minat Belajar Anak Dengan Menggunakan Teknik Kolase Dari Bahan Plastik Bekas Jajanan Di TK Negeri 1 Pembina Gunungsitoli Selatan T.P. 2014/2015. JPUD - Jurnal Pendidikan Usia Dini, 10(1), 1-28. https:// doi.org/10.21009/JPUD.101.01

Puspa Putri, D. A. (2019). Rancang Bangun Media Pembelajaran Bahasa Arab Untuk Anak Usia Dini Berbasis Android. Technologia: Jurnal Ilmiah, 10(3), 156. https:// doi.org/10.31602/tji.v10i3.2230

Putri, D. K., Handayani, M., \& Akbar, Z. (2020). Pengaruh Media Pembelajaran dan Motivasi Diri terhadap Keterlibatan Orang Tua dalam Pendidikan Anak. Jurnal Obsesi : Jurnal Pendidikan Anak Usia Dini, 4(2), 649. https:/ / doi.org/10.31004/obsesi.v4i2.418

Soesilo, T. D. (2015). Penelitian Eksperimen. Griya Media.

Sugiyono. (2012). Metode Penelitian Kuantitatif Kualitatif Dan RED. ALFABET.

Sunanti, S., Agustin, M., \& Kurniati, E. (2019). Pengaruh Pembelajaran Permainan Tradisional Galahbandung Terhadap Kecerdasan Bodili-Kinesthetic Anak Usia Dini. Edukid, 13(2). https:// doi.org/10.17509/edukid.v13i2.16922

Ubaidillah, U. (2020). Pengembangan Minat Belajar Kognitif Pada Anak Usia Dini. JCE (Journal of Childhood Education), 3(1), 41. https:/ / doi.org/10.30736/jce.v2i2.66

Wirsa, K., \& Saridewi. (2020). Studi Deskriptif Pengaruh Metode Bercerita Bilingual Terhadap Minat Belajar Anak Usia Dini. Tumbuh Kembang Anak Usia Dini, 5(2), 71-76. https://doi.org/https:// doi.org/10.14421/jga.2020.52-04

Zaini, H., \& Dewi, K. (2017). Pentingnya Media Pembelajaran Untuk Anak Usia Dini. Raudhatul Athfal: Jurnal Pendidikan Islam Anak Usia Dini, 1(1), 81-96. https:/ / doi.org/10.19109/ra.v1i1.1489

Zeptyani, P. A. D., \& Wiarta, I. W. (2020). Pengaruh Project-Based Outdoor Learning Activity Menggunakan Media Audio Visual Terhadap Perilaku Belajar Anak Usia Dini. Jurnal Undiksha, 8(2). https:/ / doi.org/10.23887/paud.v8i2.24740 